\title{
Peningkatan Kemampuan Menganalisis Keterkaitan Unsur Intrinsik Suatu Cerpen Dengan Kehidupan Sehari-Hari Melalui Metode Jigsaw Pada Siswa Kelas XII SMA Negeri 1 Lemito
}

\author{
Saidah Halid \\ Guru SMA Negeri 1 Lemito \\ saidahhalid@gmail.com
}

\begin{abstract}
Received: 04 March 2021; Revised: 26 April 2021; Accepted: 28 July 2021
DOI: http://dx.doi.org/10.37905/aksara.7.3.1107-1116.2021
\end{abstract}

\begin{abstract}
Abstrak
Penelitian ini dilaksanakan dalam dua siklus, yaitu siklus I dan siklus II dengan target nilai rata-rata atau ketuntasan minimal yaitu 70. Subjek penelitian ini adalah kemampuan menganalisis keterkaitan unsur intrinsik suatu cerpen dengan kehidupan sehari-hari melalui metode jigsaw pada siswa kelas XII SMAN 1 Lemito. Pengumpulan data siklus I dan siklus II menggunakan teknik tes dan nontes. Teknik tes berupa kemampuan menganalisis keterkaitan unsur intrinsik cerpen dengan kehidupan seharihari melalui metode jigsaw. Teknik nontes berupa pedoman observasi, pedoman wawancara, pedoman jurnal, dan pedoman dokumentasi. Teknik analisis data dilakukan secara kuantitatif dan kualitatif.

Hasil analisis data siklus I dan siklus II menunjukkan adanya peningkatan nilai rata- rata kelas. Hasil tes siklus I menunjukkan rata-rata sebesar 68,9 dan hasil tes siklus II menunjukkan nilai sebesar 80,3. Perubahan perilaku siswa kelas XII SMAN 1 Lemito mengalami peningkatan ke arah yang positif. Pada siklus I siswa cenderung pasif, kurang memperhatikan penjelasan guru, kurang serius dalam berlatih, dan kurang percaya diri. Pada siklus II, perilaku siswa berubah menjadi aktif, memperhatikan penjelasan guru, serius dalam berlatih, dan menjadi percaya diri.
\end{abstract}

Kata Kunci : keterkaitan, unsur intrinsik cerpen, kehidupan sehari-hari, metode jigsaw

\section{PENDAHULUAN}

Karya sastra merupakan hasil salah satu cabang kebudayaan, yakni kesenian. Sebagai cabang kesenian, sastra berfungsi memperjelas, memperdalam, dan memperkaya penghayatan manusia terhadap kehidupan yang sejahtera (Sumardjo dan Saini 1994:16). Karya sastra senantiasa menawarkan peran moral atau hikmah yang berhubungan dengan sifat-sifat luhur kemanusiaan, memperjuangkan hak dan martabat manusia. Sifat-sifat kemanusiaan tersebut pada hakikatnya bersifat universal, artinya sifat-sifat itu dimiliki dan diyakini oleh manusia sejagat.

Pembelajaran sastra seperti prosa, puisi, dan drama bertujuan agar siswa mampu menikmati, memahami, dan memanfaatkan karya sastra untuk mengembangkan kepribadian, memperluas wawasan kehidupan serta meningkatkan pengetahuan dan kemampuan berbahasa (Resmini,2011). Untuk memahami dan menghayati karya sastra, siswa diharapkan langsung membaca karya sastra bukan membaca ringkasannya. Tujuan akhirnya adalah menanamkan dan menumbuhkan kepekaan terhadap masalah-masalah 
manusiawi, pengenalan dan rasa hormatnya terhadap tata nilai baik konteks individu maupun sosial.

Pada saat observasi di Kelas XII SMA Negeri 1 Lemito, peneliti menemukan beberapa masalah yang menunjukkan bahwa siswa kurang antusias mengikuti pembelajaran membaca cerpen. Banyak siswa tidak serius mengikuti pembelajaran serta tidak berkonsentrasi dalam pembelajaran. Mereka masih berbicara sendiri dengan temannya, merasa jenuh dan bosan membaca cerpen, mengantuk, melamun, dan beberapa siswa pandangan matanya tertuju ke luar ruang kelas. Siswa merasa kesulitan dalam memahami isi cerpen dan mengaitkan dengan kehidupan sehari-hari. Hal ini terbukti dengan nilai rata-rata kelas 67. Nilai rata-rata ini masih belum mencapai KKM yaitu 70.

Teknik yang digunakan oleh guru tidak mengubah perilaku siswa dalam pembelajaran. Guru menggunakan teknik ceramah dan penugasan kepada siswa. Dalam teknik ini guru menerangkan secara lisan dan siswa mendengarkan, setelah kegiatan tersebut siswa diberi penugasan untuk membaca cerpen dan menemukan unsur intrinsiknya. Kegiatan pembelajaran yang digunakan oleh guru sebatas menemukan unsur intrinsik cerpen saja tanpa memperhatikan kaitan unsur-unsur intrinsik dengan kehidupan sehari-hari siswa. Hal ini dirasa masih kurang tepat untuk membelajarkan kemampuan menganalisis keterkaitan unsur intrinsik cerpen dengan kehidupan sehari-hari.

Masalah yang dihadapi sekarang adalah menentukan teknik atau strategi pembelajaran sastra agar dapat memberikan sumbangan yang maksimal untuk pendidikan secara utuh. Sementara banyak siswa yang beranggapan bahwa pembelajaran mengapresiasi karya sastra merupakan pembelajaran yang sulit, tentu termasuk juga tentang cerita pendek, sehingga siswa kurang termotivasi untuk mempelajarinya. Kesulitan-kesulitan yang dialami siswa dalam mengapresiasi cerpen tersebut kemungkinan disebabkan oleh kemampuan siswa yang kurang atau pemilihan metode dari guru yang kurang tepat.

Selain itu guru masih masih melaksanakan pembelajaran yang teoretis. Guru masih melihat pengetahuan dan pemahaman konsep yang diberikan oleh guru melalui metode ceramah. Hal itu bisa dilihat pada fakta pembelajaran, guru masih menilai teori saja seperti pertanyaan seputar unsur intrinsik. Dalam pembelajaran guru memberi pertanyaan yang dirasa membuat siswa menjadi kurang termotivasi dalam belajar.

Ada beberapa kelemahan dari teknik ceramah antara lain, (1) pengajar tidak dapat mengetahui pemahaman siswa tentang materi yang disampaikan, (2) kata-kata yang diucapkan pengajar ditafsirkan lain oleh pembelajar. Teori tersebut ternyata sama dengan yang peneliti alami setelah melakukan observasi. Itulah beberapa penyebab kegagalan dalam pembelajaran cerita pendek. Kegagalan tersebut terlihat dari banyaknya siswa yang masih mengalami ketidakjelasan dalam memahami cerita pendek.

Menurut Dzamarah dan Zain (2005:56) guru yang hanya menggunakan satu metode biasanya sukar menciptakan suasana kelas yang kondusif dalam waktu relatif lama. Bila terjadi perubahan suasana kelas, sulit menormalkannya kembali. Ini sebagai tanda adanya gangguan dalam proses pembelajaran. Akibatnya, jalannya pembelajaran kurang menjadi efektif.

Oleh karena itu, diperlukan strategi atau pemilihan metode pembelajaran yang sesuai kebutuhan siswa agar kemampuan siswa dalam mengapresiasi sastra khususnya cerpen yaitu menganalisis keterkaitan unsur intrinsik cerpen dengan kehidupan seharihari. Dari berbagai masalah yang ada, peneliti tertarik untuk mengadakan penelitian 
tindakan kelas. Penelitian ini dilakukan pada Kelas XII karena didasari bahwa KD tentang menganalisis keterkaitan unsur-unsur intrinsik cerpen dengan kehidupan sehari-hari terdapat pada Kelas XII.

Berdasarkan observasi tersebut, peneliti akan mencoba menerapkan salah satu metode yaitu metode pembelajaran kooperatif tipe Jigsaw. Siswa dalam pembelajaran kelompok kooperatif belajar berdiskusi, saling membantu, dan mengajak satu sama lain untuk mengatasi masalah belajar. Pembelajaran kooperatif mengkondisikan siswa untuk aktif dan saling memberi dukungan dalam kerja kelompok untuk menuntaskan masalah dalam belajar. Tipe Jigsaw melibatkan seluruh siswa dalam belajar dan sekaligus siswa belajar serta mengajarkan apa yang dipelajari kepada orang lain.

\section{METODE PENELITIAN}

Desain penelitian ini menggunakan prosedur penelitian tindakan kelas (PTK). Dengan demikian, penelitian ini berbasis kelas yang meilbatkan komponen yang ada di dalam kelas yaitu siswa, guru, materi pelajaran, dan metode pembelajaran yang terangkum dalam proses pembelajaran di dalam kelas.

Penelitian tindakan kelas ini mencakup 4 aspek pokok, yaitu (1) perencanaan, (2) tindakan, (3) observasi, (4) refleksi. Penelitian ini dilakukan dengan dua siklus yaitu siklus I dan siklus II.

Pada perencanaan siklus I dilakukan persiapan pembelajaran menganalisis keterkaitan unsur intrinsik cerpen dengan kehidupan sehari-hari melalui metode jigsaw: 1) menyusun rencana pelaksanaan pembelajaran menganalisis keterkaitan unsur intrinsik cerpen dengan kehidupan sehari-hari melalui metode jigsaw, 2) menentukan cerpen yang akan digunakan, 3) mempersiapkan instrumen penilaian yaitu instrumen tes dan nontes. Instrumen tes berupa tes menganalisis keterkaitan unsur intrinsik cerpen dengan kehidupan sehari-hari beserta kriteria penilaiannya, dan instrumen nontes berupa pedoman observasi, jurnal siswa dan guru, pedoman wawancara, dan pedoman dokumentasi foto, 4) menyiapkan perangkat tes menganalisis keterkaitan unsur intrinsik dengan kehidupan sehari-hari yang berupa soal tes, pedoman penskoran, dan penilaian, 5) berkolaborasi dengan guru mata pelajaran dan kelas yang akan diteliti.

\section{HASIL DAN PEMBAHASAN}

Hasil penelitian yang diuraikan berupa hasil tes dan nontes, baik pada siklus I maupun siklus II. Tindakan siklus I dan II disetiap tesnya terdiri atas tujuh aspek, yaitu aspek keterkaitan tema dengan kehidupan sehari-hari, keterkaitan alur dengan kehidupan sehari-hari, keterkaitan latar dengan kehidupan sehari-hari, keterkaitan tokoh dan penokohan dengan kehidupan sehari-hari, keterkaitan amanat dengan kehidupan seharihari, keterkaitan sudut pandang dengan kehidupan sehari-hari, keterkaitan gaya bahasa dengan kehidupan sehari-hari. Data nontes yang diuraikan pada siklus I dan siklus II berupa observasi, wawancara, jurnal, dan dokumentasi foto.

Siklus I adalah tindakan awal pembelajaran menganalisis keterkaitan unsur intrinsik cerpen dengan kehidupan sehari-hari dengan metode Jigsaw. Tindakan pada siklus I ini dilaksanakan sebagai salah satu upaya mengatasi permasalahan dalam pembelajaran kemampuan menganalisis keterkitan unsur intrinsik cerpen dengan kehidupan sehari-hari siswa Kelas XII SMA Negeri 1 Lemito. 
Proses pembelajaran menganalisis keterkaitan unsur intrinsik cerpen dengan kehidupan sehari-hari melalui metode jigsaw antara lain: 1) intensif atau tidaknya proses penumbuhan minat siswa untuk menganalisis keterkaitan unsur intrinsik cerpen dengan kehidupan sehari-hari, 2) kondusif atau tidaknya proses diskusi dalam kelompok ahli untuk menentukan materi keterkaitan unsur-unsur yang terdapat dalam cerpen dengan kehidupan sehari-hari, 3) kondusif atau tidaknya proses diskusi dalam kelompok asal untuk menyampaikan temuan tentang materi keterkaitan unsur-unsur yang terdapat dalam cerpen dengan kehidupan sehari-hari, 4) intensif atau tidaknya proses evaluasi dalam menemukan keterkaitan unsur intrinsik cerpen dengan kehidupan sehari-hari, 5) reflektif atau tidaknya suasana saat kegiatan refleksi pada akhir pembelajaran

Berdasarkan tabel diketahui proses pembelajaran menganalisis keterkaitan unsur intrinsik cerpen dengan kehidupan sehari-hari melalui metode jigsaw cukup baik. Dalam pembelajaran menganalisis keterkaitan unsur intrinsik cerpen dengan kehidupan seharihari melalui metode jigsaw tercatat 32 atau sebesar $80 \%$ dalam kategori baik siswa berminat untuk mengikuti pembelajaran, sebanyak 24 siswa atau sebesar $60 \%$ dalam kategori kurang kondusif pada proses diskusi dalam kelompok ahli untuk menentukan materi keterkaitan unsur-unsur yang terdapat dalam cerpen dengan kehidupan sehari-hari, sebanyak 30 siswa atau $75 \%$ termasuk kategori baik siswa mampu berdiskusi secara kondusif pada proses diskusi dalam kelompok asal untuk menyampaikan temuan tentang materi keterkaitan unsur-unsur yang terdapat dalam cerpen dengan kehidupan sehari-hari.

Hasil tes menganalisis menganalisis keterkaitan unsur intrinsik suatu cerpen dengan kehidupan sehari-hari melalui metode jigsaw yang dilakukan oleh peneliti pada siklus I belum mencapai nilai ketuntasan belajar yaitu 70. Sebanyak 20 siswa atau sekitar $50 \%$ dari 40 siswa masih memperoleh nilai dibawah 70 sedangkan nilai rata-rata siswa hanya 68,92. Hal ini disebabkan oleh 4 aspek yang dinilai masih memiliki kategori cukup sampai kurang baik. Kekurangan yang masih ada pada siklus I akan diperbaiki dan dijadikan sebagai acuan untuk mengadakan siklus II

Hasil tes menganalisis menganalisis keterkaitan unsur intrinsik suatu cerpen dengan kehidupan sehari-hari melalui metode jigsaw yang dilakukan oleh peneliti pada siklus II sudah mencapai nilai ketuntasan belajar yaitu 81,9. Kategori sangat baik diraih oleh 17 siswa dan 23 siswa mendapat nilai baik. Semua aspek penilaian telah mencapai nilai lebih dari 70 .

Berdasarkan hasil observasi, wawancara, jurnal, dan dokumentasi foto dapat diketahui perilaku siswa tergolong baik. Siswa terlihat lebih serius dalam mengerjakan tugas yang diberikan guru. Siswa merasa senang mengikuti pembelajaran menganalis keterkaitan unsur intrinsik cerpen dengan kehidupan sehari- hari. Perilaku siswa saat berdiskusi dalam kelompok asal berubah menjadi lebih baik. Sebagian besar siswa relatif tidak lagi hanya menyalin pekerjaan teman dari kelompok ahli lain, tetapi siswa juga berdiskusi dan memahami penjelasan siswa dari kelompok ahli lain.

Beberapa siswa realtif antusias dalam mengikuti pembelajaran menganalisis keterkaitan unsur intrinsik cerpen dengan kehidupan sehari-hari melalui metode jigsaw. Selama proses pembelajaran beberapa siswa tampak tenang dan memperhatikan penjelasan yang disampaikan oleh guru.

Setelah melakukan pembelajaran siklus II diketahui masalah-masalah yang dihadap siswa tidak terlihat lagi. Siswa mampu memperbaiki pembelajaran menganalisis keterkaitan unsur intrinsik cerpen dengan kehidupan sehari-hari melalui metode jigsaw. 
Siklus II merupakan tindakan perbaikan dari pembelajaran siklus I. Hasil tes siswa pada siklus II mengalami peningkatan dari siklus I dan sudah mencapai nilai rata-rata klasikal yang diharapkan. Sehingga siklus III tidak perlu diadakan. Penelitian ini dilakukan selama dua siklus. Tiap siklus dilakukan melalui beberapa tahap, yaitu perencanaan, observasi, tindakan, dan refleksi. Siklus II dilakukan sebagai wujud perbaikan dari pembelajaran siklus I. Hasil penelitian pada siklus I dan II dijaring menggunakan instrumen penjaring data, baik melalui tes maupun nontes. Berdasarkan hasil kedua siklus tersebut diketahui peningkatan kemampuan siswa dalam menganalisis keterkaitan unsur intrinsik cerpen dengan kehidupan sehari-hari melalui metode jigsaw, serta perubahan perilaku yang ditunjukkan oleh siswa. Berikut ini uraian pelaksanaan perolehan data pada siklus I dan siklus II.

Proses pembelajaran menganalisis keterkaitan unsur intrinsik cerpen dengan kehidupan sehari-hari melalui metode jigsaw pada siklus I dan siklus II dilaksanakan dengan indikator proses antara lain: 1) intensif atau tidaknya proses penumbuhan minat siswa untuk menganalisis keterkaitan unsur intrinsik cerpen dengan kehidupan seharihari, 2) kondusif atau tidaknya proses diskusi dalam kelompok ahli untuk menentukan materi keterkaitan unsur-unsur yang terdapat dalam cerpen dengan kehidupan sehari-hari, 3) kondusif atau tidaknya proses diskusi dalam kelompok asal untuk menyampaikan temuan tentang materi keterkaitan unsur-unsur yang terdapat dalam cerpen dengan kehidupan sehari-hari, 4) intensif atau tidaknya proses evaluasi dalam menemukan keterkaitan unsur intrinsik cerpen dengan kehidupan sehari-hari, 5) reflektif atau tidaknya suasana saat kegiatan refleksi pada akhir pembelajaran.

Dalam pembelajaran menganalisis keterkaitan unsur intrinsik cerpen dengan kehidupan sehari-hari melalui metode jigsaw siklus I tercatat 32 atau sebesar $80 \%$ dalam kategori baik siswa berminat untuk mengikuti pembelajaran, dan pada siklus II sebanyak 35 siswa atau $87,5 \%$ siswa berminat mengikuti pembelajaran. Terjadi peningkatan pada aspek ini yaitu sebesar 7,5\%. Pada aspek kedua siklus I terdapat 24 siswa atau sebesar $60 \%$ dalam kategori kurang kondusif pada proses diskusi dalam kelompok ahli untuk menentukan materi keterkaitan unsur-unsur yang terdapat dalam cerpen dengan kehidupan sehari-hari dan mengalami peningkatan pada siklus II sebanyak 17,5\% menjadi 31 siswa atau 77,5\%. Pada aspek ketiga siklus I, sebanyak 30 siswa atau 75\% termasuk kategori baik siswa mampu berdiskusi secara kondusif pada proses diskusi dalam kelompok asal untuk menyampaikan temuan tentang materi keterkaitan unsurunsur yang terdapat dalam cerpen dengan kehidupan sehari-hari. Pada siklus II aspek ketiga mengalami peningkatan 2,5\% sebanyak 31 siswa atau 77,5\% kondusif pada proses diskusi kelompok asal.

Pada aspek keempat siklus I sebanyak 35 siswa atau sebesar 87,5\% termasuk kategori sangat baik siswa mampu mengikuti proses evaluasi dalam menemukan keterkaitan unsur intrinsik cerpen dengan kehidupan sehari-hari secara intensif. Pada siklus II aspek keempat ini mengalami pening katan sebesar 5\% menjadi sebanyak 37 siswa atau 92,5\%. Aspek terakhir siklus I sebanyak 36 siswa atau 90\% siswa mampu mengikuti kegiatan refleksi dengan baik. Aspek kelima mengalami peningkatan pada siklus II sebesar 5\% menjadi sebanyak 38 siswa atau 95\% siswa mampu mengikuti kegiatan refleksi dengan baik.

Pembahasan hasil penelitian ini didasarkan pada hasil siklus I dan siklus II. Pembahasan hasil tes berpedoman pada pemerolehan nilai yang dicapai siswa dalam tes 
unjuk kerja menganalisis keterkaitan unsur intrinsik cerpen dengan kehidupan sehari-hari. Aspek-aspek yang dinilai meliputi (1) aspek keterkaitan tema dengan kehidupan seharihari, (2) keterkaitan alur dengan kehidupan sehari-hari, (3) keterkaitan latar dengan kehidupan sehari-hari, (4) keterkaitan tokoh dan penokohan dengan kehidupan seharihari, (5) keterkaitan amanat dengan kehidupan sehari-hari, (6) keterkaitan sudut pandang dengan kehidupan sehari-hari, (7) keterkaitan gaya bahasa dengan kehidupan sehari-hari. Peningkatan nilai yang dicapai dapat dirinci berdasar tiap aspek. Pada aspek keterkaitan tema dengan kehidupan sehari-hari dari siklus I ke siklus II tidak mengalami kenaikan nilai rata-rata, namun sebaran jawaban siswa lebih bervariasi. Hal ini menunjukkan siswa tidak lagi hanya menerima jawaban dari teman lain tetapi juga hasil pemikiran mereka sendiri. Aspek keterkaitan alur dengan kehidupan sehari- hari dari siklus I ke siklus II mengalami kenaikan sebesar 30,5 atau 76,2\%. Aspek keterkaitan latar dengan kehidupan sehari-hari dari siklus I ke siklus II mengalami kenaikan sebesar 4,5 atau 5,8\%.

Adapun pada aspek keterkaitan tokoh dan penokohan dengan kehidupan seharihari dari siklus I ke siklus II mengalami peningkatan sebesar 27,0 atau 50,5\%. Aspek keterkaitan amanat dengan kehidupan sehari-hari dari siklus I ke siklus II mengalami kenaikan sebesar 5,0 atau 6,3\%. Aspek keterkaitan sudut pandang dengan kehidupan sehari-haridari siklus I ke siklus II mengalami kenaikan sebesar15,5 atau 23,8\%. Aspek keterkaitan gaya bahasa dengan kehidupan sehari-hari dari siklus I ke siklus II mengalami kenaikan sebesar 22,0 atau 36,4\%.

Pada siklus I hasil tes menunjukkan bahwa nilai rata-rata klasikal belum memenuhi nilai ketuntasan yang telah ditetapkan. Nilai rata-rata siswa siklus I 68,9. Meskipun nilai tersebut lebih tinggi dari nilai rata-rata klasikal sebelumnya namun tetap belum mencapai nilai ketuntasan yang telah ditetapkan yaitu 70. Pada siklus I hasil nontes belum memuaskan karena masih banyak siswa yang relatif pasif dalam pembelajaran serta suasana kelas yang kurang kondusif. Hal ini mempengaruhi hasil tes siswa yang kurang memuaskan. Walaupun demikian siswa menjadi lebih antusias dalam mengikuti pembelajaran menganalisis keterkaitan unsur intrinsik cerpen dengan kehidupan seharihari. Pada siklus II terjadi peningkatan dari siklus I baik dalam hasil tes maupun nontes. Peningkatan hasil tes siswa dari siklus I ke siklus II sebesar 11,4 atau 16,5\%.

Nilai rata-rata pada siklus I 68,9 menjadi 81,9 pada siklus II. Peningkatan tersebut terjadi karena perbaikan perencanaan dan tindakan yang dilakukan pada siklus II. Peningkatan juga terjadi pada perilaku siswa yang menjadi lebih baik. Perilaku siswa terjaring dari instrumen nontes yang telah dianalisis. Hasil analisis nontes menunjukkan perubahan perilaku siswa diantaranya siswa menjadi lebih aktif dalam pembelajaran. Selain itu, suasana kelas pada siklus I masih relatif kurang kondusif karena siswa masih ramai dalam mengikuti pembelajaran. Suasana kelas pada siklus II menjadi lebih kondusif dan siswa lebih tenang dalam mengikuti pembelajaran. Berdasarkan penjelasan pada hasil tes dan nontes siklus II dapat disimpulkan bahwa target penelitian tindakan Kelas XII SMAN 1 Lemito telah tercapai. Oleh karena itu, penelitian tidak dilanjutkan pada siklus III.

Berdasarkan penjelasan tersebut terjadi peningkatan kemampuan menganalisis keterkaitan unsur intrinsik cerpen dengan kehidupan sehari-hari melalui metode jigsaw dari siklus I ke siklus II baik dari hasil tes maupun nontes. Hal tersebut menunjukkan bahwa penelitian ini telah mencapai hasil yang diharapkan oleh peneliti dalam mengatasi 
masalah dalam pembelajaran menganalisis keterkaitan unsur intrinsik cerpen dengan kehidupan sehari-hari Kelas XII SMAN 1 Lemito.

Penelitian ini memberikan bukti bahwa penggunaan metode jigsaw dalam pembelajaran menganalisis keterkaitan unsur intrinsik cerpen dengan kehidupan seharihari pada siswa Kelas XII SMAN 1 Lemito dapat digunakan sebagai salah satu alternatif metode pembelajaran yang efektif dalam pembelajaran menganalisis keterkaitan unsur intrinsik keterkaitan cerpen dengan kehidupan sehari-hari. Oleh karena itu, tindakan selanjutnya yang akan dilakukan setelah keberhasilan yang tercapai dalam pembelajaran menganalisis keterkaitan unsur intrinsik cerpen dengan kehidupan sehari-hari melalui metode jigsaw pada siswa Kelas XII SMAN 1 Lemito adalah menerapkan metode jigsaw dalam pembelajaran menganalisis keterkaitan unsur intrinsik cerpen dengan kehidupan sehari-hari pada siswa Kelas XII lainnya di SMAN 1 Lemito. Hal tersebut diharapkan dapat meningkatkan kemampuan menganalisis keterkaitan unsur intrinsik cerpen dengan kehidupan sehari-hari. Sehingga pembelajaran apresiasi cerpen menjadi lebih bermakna dan dapat bermanfaat bagi kehidupan siswa.

\section{PENTUTUP}

Proses pembelajaran menganalisis keterkaitan unsur intrinsik cerpen dengan kehidupan sehari-hari mengalami peningkatan dari siklus I ke siklus II. Dalam pembelajaran menganalisis keterkaitan unsur intrinsik cerpen dengan kehidupan seharihari melalui metode jigsaw siklus I tercatat 32 atau sebesar $80 \%$ dalam kategori baik siswa berminat untuk mengikuti pembelajaran, dan pada siklus II sebanyak 35 siswa atau $87,5 \%$ siswa berminat mengikuti pembelajaran. Terjadi peningkatan pada aspek ini yaitu sebesar 7,5\%. Pada aspek kedua siklus I terdapat 24 siswa atau sebesar $60 \%$ dalam kategori kurang kondusif pada proses diskusi dalam kelompok ahli untuk menentukan materi keterkaitan unsur-unsur yang terdapat dalam cerpen dengan kehidupan sehari-hari dan mengalami peningkatan pada siklus II sebanyak 17,5\% menjadi 31 siswa atau 77,5\%. Pada aspek ketiga siklus I, sebanyak 30 siswa atau 75\% termasuk kategori baik siswa mampu berdiskusi secara kondusif pada proses diskusi dalam kelompok asal untuk menyampaikan temuan tentang materi keterkaitan unsur-unsur yang terdapat dalam cerpen dengan kehidupan sehari-hari. Pada siklus II aspek ketiga mengalami peningkatan 2,5\% sebanyak 31 siswa atau 77,5\% kondusif pada proses diskusi kelompok asal. Pada aspek keempat siklus I sebanyak 35 siswa atau sebesar 87,5\% termasuk kategori sangat baik siswa mampu mengikuti proses evaluasi dalam menemukan keterkaitan unsur intrinsik cerpen dengan kehidupan sehari-hari secara intensif. Pada siklus II aspek keempat ini mengalami pening katan sebesar 5\% menjadi sebanyak 37 siswa atau 92,5\%. Aspek terakhir siklus I sebanyak 36 siswa atau 90\% siswa mampu mengikuti kegiatan refleksi dengan baik. Aspek kelima mengalami peningkatan pada siklus II sebesar 5\% menjadi sebanyak 38 siswa atau 95\% siswa mampu mengikuti kegiatan refleksi dengan baik.

Hasil tes penelitian ini menunjukkan adanya peningkatan hasil tes yang dilakukan pada siswa kelas Kelas XII SMAN 1 Lemito . Hasil tes pada siklus I memperoleh nilai rata-rata 68,9. Hasil tes siklus I belum mencapai KKM yaitu 70. Pada siklus II siswa memperoleh nilai rata-rata 81,9. Peningkatan keterampilan tersebut disebabkan oleh meningkatnya pemahaman siswa terhadap materi keterkaitan unsur intrinsik cerpen dengan kehidupan sehari-hari. Hal tersebut terbukti dengan rata-rata nilai siswa telah 
mencapai batas ketuntasan minimal. Peningkatan nilai rata-rata ini membuktikan keberhasilan pembelajaran menganalisis keterkaitan unsur intrinsik cerpen dengan kehidupan sehari-hari melalui metode jigsaw pada siswa kelas Kelas XII SMAN 1 Lemito.

Perubahan perilaku siswa Kelas XII SMAN 1 Lemito mengalami peningkatan ke arah yang positif setelah dilaksanakan pembelajaran menganalisis keterkaitan unsur intrinsik cerpen dengan kehidupan sehari-hari melalui metode jigsaw. Hal tersebut dapat dketahui dari hasil nontes yang meliputi hasil observasi, wawancara, jurnal, dan dokumentasi foto. Pada siklus I siswa cenderung pasif, kurang memperhatikan penjelasan guru, kurang serius dalam berlatih, dan kurang percaya diri. Setelah dilakukan pembelajaran pada siklus II, perilaku siswa berubah menjadi aktif, memperhatikan penjelasan guru, serius dalam berlatih, dan menjadi percaya diri.

\section{DAFTAR PUSTAKA}

Aminuddin. 2002. Pengantar Apresiasi Sastra. Bandung: Sinar Baru Algesindo Amri, Sofan dan Iif Khoiru Ahmadi. 2009. Proses Pembelajaran Inovatif dan Kreatif dalam Kelas. Jakarta: Prestasi Pustaka

Aryani, Sekar Ayu.2008. Strategi Pembelajaran Aktif. Yogyakarta: Insan Madani Damono, Sapardi Djoko. 2006. "Pengarang, Karya Sastra, dan Pembaca”. Jurnal Lingua. Volume I, Nomor I , Halaman 51-61. ISSN: 1693-4725

Efendi, Anwar. 2010. "Analisis Perbandingan Struktural Cerpen "Selamat Jalan Nek" Karya Danarto dan Cerpen "Pohon" Karya Monaj Das". Jurnal Litera. Volume 9, Nomor 2. Halaman 82-96. ISSN: 1412-2596

Indriasih, Aini. 2009. "Penerapan Pembelajran Kooperatif Jigsaw untuk Meningkatkan Hasil Belajar IPS di SD". Jurnal Pendidikan. Volume 10. September 2009. Halaman 78-84. ISSN:1411-1942

Ibrahim, R dan Nana Syaodih. 2003. Perencanaan Pengajaran. Jakarta: Rineka Cipta Isjoni. 2009. Cooperative Learning (Efektivitas Pembelajaran Kelompok). Yogyakarta: Pustaka Pelajar

Ismawati, Esti. 2011. "Pengembangan Penilaian Pembelajaran bahasa dan Sastra Indonesia Berbasis Konstekstual" diunduh melalui http://journal.unwidha.ac.id/index.php/procceding/article/download/268/21 7 pada 25 Agustus 2013

Marno dan Idris. 2009. Strategi \& Metode Pengajaran. Yogyakarta: Ar-Ruzz Media

Mulyani, Wahyu. 2010. "Membidik Kehidupan Rakyat Kecil di Balik Gaya Bahasa Metafora dalam "Senyum" Karyamin Karya Ahmad Tohari”. Prospektus Jurnal Ilmiah Unirow Tuban. Vol VII, Nomor 1, Halaman 54- 62. ISSN: 1693-8593

Mulyono. 2006. "Popularitas Sastra Islami di Indonesia". Jurnal Lingua. Volume I, Nomor I, Halaman 32-41. ISSN: 1693-4725

Nurgiyantoro, Burhan. 2001. Teori Pengkajian Fiksi. Yogyakarta: Gadjah Mada University Press

Nursisto. 2004. Ikhtisar Kesusastraan Indonesia. Jakarta: Pay Cita

Nuryatin, Agus. 2010. Mengabadikan Pengalaman dalam Cerpen. Semarang: Yayasan Adhigama 
Pujiastuti, Emi dan Amin Suyitno. 2009. "Implementasi Cooperative Learning Tipe Jigsaw II Berbasis Kontekstual untuk Meningkatkan Kompetensi Dasar Mahasiswa Pendidikan Matematika Unnes dalam Perkuliahan Kalkulus Lanjut”. Jurnal Penelitian Pendidikan. Vol. 26. Oktober 2009. Hal 143-149. ISSN:1978-8304

Rahmanto, B. 1996. Metode Pengajaran Sastra. Yogyakarta: Kanisius Rahmawati, Dwi Norma. 2007. "Peningkatan Kemampuan Memahami Alur,

Penokohan, dan Latar dalam Cerpen dengan Teknik Diskusi Kelompok pada Siswa Kelas XIII MAN Pagerbarang Kabupaten Tegal”. Skripsi. Universitas Negeri Semarang

Rasmi, Ni Nengah. 2006. "Peningkatan Mutu Pengajaran Teori Sastra Melalui Pemberian Pengalaman Membaca Karya Sastra Siswa Kelas I SMU Laboratorium IKIP Negeri Singaraja". Jurnal Pendidikan dan Pengajaran. Vol. 39. April 2006. Halaman 356376. ISSN: 0215-8250

Resmini. 2011.’Pembelajaran Apresiasi Bacaan Cerita Melalui Implementasi Strategi Directed Reading Activity“ diunduh melalui http://file.upi.edu/direktori/fpbs/jur._pend._bhs._dan_sastra_indonesia/196 711031993032novi_resmini/pengajaran_sastra_dengan_drta_\%28artikel_j urnal_sekolah_dasar_malang\%29.pdf pada 11 Agustus 2013

Sasmito, Muji. 2010. "Peningkatan Keterampilan Menulis Cerpen dengan Memanfaatkan Situs Cerpenista.Com Siswa Kelas XII2 SMA Negeri 7 Semarang”. Skripsi. Universitas Negeri Semarang

Siskandar. 2009. "Keefektifan Pendekatan Cooperative Learning dalam Meningkatkan Aktivitas dan Hasil Belajar Mahasiswa". Jurnal Ilmu Pendidikan. Vol 16. Oktober 2009. Halaman 178- 185. ISSN: 0215-9643

Situmeang, Dahriansyah. 2012. "Efektivitas Model Pembelajaran Cooperatif Learningtipe Stad dalam Meningkatkan Kemampuan Menganalisis Unsur Intrinsik Cerpen "Daerah Garong" Karya M. Shoim Anwar Oleh Siswa Kelas XIIi Sma Negeri 1 Sibolga Tahun Pembelajaran 2010/2011" Asas Jurnal Sastra. Vol I. Halaman 53-62 ISSN: 2301-5896

Slavin, Robert E. 2012. Cooperative Learning Teori, riset, dan Praktik. Bandung: Nusa Media

Suharianto. S. 1982. Dasar-Dasar Teori Sastra. Surakarta: Widya Duta Sumardjo, Jakob, dan Saini. 1994. Apresiasi Kesusatraan. Jakarta: Gramedia Pustaka Utama

Suprijono. 2009. Cooperative Learning Teori dan Aplikasi PAIKEM. Yogyakarta: Pustaka Pelajar

Suryosubroto. 2009. Proses Belajar Mengajar di Sekolah. Jakarta: Rineka Cipta Syarifah.

Eri. 2009. Pembelajaran Inovatif Bahasa Indonesia. Semarang: Bandungan Institude

Tarigan, Henry Guntur. 1997. Membaca sebagai Suatu Keterampilan Berbahasa. Bandung: Angkasa

Teeuw, A. 1988. Sastra dan Ilmu Sastra Pengantar Teori Sastra. Jakarta: Girimukti Pasaka 
AKSARA: Jurnal Ilmu Pendidikan Nonformal

P-ISSN 2407-8018 E-ISSN 2721-7310 DOI prefix $\underline{10.37905}$

Volume 07, (03) September 2021

http://ejurnal.pps.ung.ac.id/index.php/Aksara

1116 AKSARA: Jurnal Ilmu Pendidikan Nonformal 